\title{
Self-employment: Deviation or the norm?
}

\section{SiMON BRIDGE}

\begin{abstract}
In many countries self-employment has increased recently. But, despite evidence that many people enter self-employment willingly out of choice, there appears to be an instinctive aversion to it, possibly based on an assumption that employment is more desirable and beneficial and is, and should be, the norm. Often using a UK viewpoint, this paper examines the history of work and suggests that, in historical terms, employment is the exception not the norm. The age of the job, it is claimed, lasted only from 1840 to 1980 , but its influence continues and many government regulations and union practices are still based on the era of the big business, big labour and big government triumvirate. Therefore, if the future is not to be constrained by laws and practices designed for the past, it is important to identify the perceptions and assumptions which prevail about employment and to highlight those which are incorrect.
\end{abstract}

Keywords: employment, the age of the job, Fordism, professions, self-employment

Received 16 January 2016. Accepted 9 April 2016

\section{INTRODUCTION}

This paper examines the history of self-employment to see whether it should be seen as an aberration and a deviation from desirable practice or instead accepted as the norm. Frequently the paper uses UK examples, not only because they are available and relatively familiar to the author, but also because the long history of work in the UK is relatively well documented and at critical times, such as the industrial revolution, the UK has been the leader in the evolving development and change.

In many countries the rate of self-employment has been increasing in recent years (D'Arcy \& Gardiner, 2014; Hatfield, 2015). For example: 'by the end of 2014 there were almost three quarters of a million more self-employed in the UK workforce than at the start of the global financial crisis in early 2008' (Henley, 2015: 2). In other countries, if the rate is not actually increasing, it is still very significant: in the USA 'self-employed Americans and the workers they hired accounted for 44 million jobs in 2014, or 30\% of the national workforce' (Kochlar, Kim, \& Rohal, 2015: 5). It has been suggested that this is due largely to the push factor of unemployment resulting from that crisis but, according to Henley, this was generally not the case:

Structural growth in self-employment in the UK began well before the onset of the global financial crisis ... (and) despite recent commentary to the contrary, that this is the outcome of voluntary choices made by individuals who in part respond to local signals about economic opportunity. The self-employed do not appear to be reluctant converts to entrepreneurship, 'encouraged' into business start-up activity by the absence of (well paid) local jobs (Henley, 2015: 10).

Ulster Business School, Ulster University, Belfast, Northern Ireland, UK

Corresponding author: simonbridge@btconnect.com 
In situations where economic growth and more jobs are being sought this apparently high level of selfemployment might seem to be encouraging but it has not always been welcomed. The conclusion from evidence, such as that indicated above, that most people do not enter self-employment as the least worst option, is resisted and suggestions are made that people are being forced reluctantly into self-employment by factors such as a lack of other opportunities, employers trying to reduce their liabilities for employees, or to register for tax-credits. And other reservations about self-employment which are also advanced include:

- It is bad for the people concerned - for instance, because it is 'nonstandard employment' (Gunderson, 2013: 26) and the self-employed are disadvantaged by having to undertake precarious work with little in the way of security or employment rights (D’Arcy \& Gardiner, 2014).

- It is bad for other businesses - for instance, because the self-employed can somehow compete unfairly by evading compliance costs (HM Revenue \& Customs, 2009).

- It is bad for the economy - for instance, because the high level of self-employment indicates that the economic recovery is shaky (D’Arcy \& Gardiner, 2014) and the self-employed are in some way avoiding taxation (HM Revenue \& Customs, 2009).

But where is the evidence in support of such concerns - or are they based more on attitudes? Is there in some quarters a sort of instinctive aversion to self-employment based on an assumption that employment is somehow the norm, or should at least be the desired state? Therefore is self-employment seen as a deviation from that norm and generally not as acceptable, worthwhile or economically beneficial as employment?

\section{WHY WORK, AND WHAT ARE THE OPTIONS?}

What should be considered to be a normal or acceptable form of work? Throughout history almost everyone has engaged in some form of work throughout most of their lives and they have done this to address their needs which, Maslow suggested, come in a hierarchy starting with basic survival needs and then rising, through safety, belonging and esteem needs, to a need for self-actualization (Maslow, 1943).

Work can meet needs directly or indirectly. Someone who is hungry can satisfy that hunger directly by working to hunt or gather food - or indirectly by working to earn money with which to buy food. Overall, it is suggested, the reason that many people work is to obtain the resources they need for aspects of living. There are a variety of ways in which they might do this - as Table 1 suggests.

Some of the means listed in Table 1 do not appear to involve much work. However they, and in particular those towards the bottom of the list such as marrying, winning or inheriting wealth, are only available to relatively few people and, although crime has always been an option, it is an illegal and/or anti-social one. The main resource generating options that, at different stages of human history or in different places, have been available to people have been one or more of hunter-gathering, farming, working for someone else or having a business enterprise. The next section therefore considers how these forms of work have evolved.

\section{THE EVOLUTION OF WORK}

\section{Hunter-gathering}

The ancestors of modern humans may have diverged from the ancestors of today's apes about 7 million years ago, but it is clear that for most of those 7 million years the members of the human branch continued to feed themselves by catching wild animals and fish and gathering wild plants and fruit. It also seems that they did this while living in relatively small mobile family or tribal groups, not least because 
- Hunter-gathering

- Self-sufficient agriculture

- Employment

- A business enterprise (e.g., a business, freelancing or self-employment)

- Crime (or other anti-social methods such as warfare, conquest or plunder)

- Unemployment or invalidity benefit payments

- Begging, or living off friends or relatives

- Acquiring a pension or annuity

- Inheriting wealth

- Marrying wealth

- Sponsorship

- Winning the lottery, or other forms of gambling

Note. Table 1 is based on Bridge (2010: 153, table 9.2), reproduced with permission from Palgrave Macmillan for author's re-use.

hunter-gathering does not usually support large concentrated static populations (Diamond, 1998: 86-89). Observation of surviving hunter-gatherer societies suggests that everything is done more or less by everyone in and for the family group - and certainly there are no such things as distinct public, private and third economic sectors. Thus, in practice, hunter-gathering was then the only available means of securing life resources - apart possibly by taking them from others in occasional bouts of intertribal warfare.

\section{Early agriculture}

It appears that it was only about 11,000 years ago that some people began to develop an alternative to hunter-gathering by starting what is now seen as the agricultural revolution. They produced food by domesticating some wild animals and cultivating some wild plants. Although peasant farmers usually have to work for more hours per day than hunter-gatherers (Diamond, 1998: 105), nevertheless by using agricultural techniques it is possible to extract more food from a given area of land and somewhat more dependably. Also, as well as more food, agriculture permitted population increases by facilitating shorter birth intervals as the nomadic existence of most hunter-gatherers means that mothers cannot look after a second child until the first no longer needs to be carried from place to place (Diamond, 1998: 89). The archaeological evidence does indeed indicate that population densities increased as agriculture was introduced, although it is not clear which was cause and which effect.

Another feature of agriculture was that it facilitated the storage of food and food which can be stored is more useful for trading. When hunter-gatherers collected more food than they needed often there was little they could do to preserve and protect the surplus and so, if it could not be exchanged immediately, it was of little value. Farmers, however, could store grain in granaries and store meat in the form of live animals in their fields. Then, with such storable surpluses, they could trade and/or or pay dues to a higher authority. Hunter-gatherers have few or no full-time specialists as everyone generally participates in the hunting or gathering - and societies do not seem to have developed very far socially through huntergathering. However agriculture, with its ability to exchange or pass on surpluses, facilitates specialists and the development of stratified societies in which those in the higher levels can have the time and inclination for innovation (Diamond, 1998: 90). Necessity may be the mother of invention, but innovations need both to be useful and to have the necessary society support for their development. Writing, for instance, may have been developed to record taxes gathered but, for its evolution beyond that, it also needed a society which could support the scribes who learnt and specialized in it. 


\section{Early work outside the family unit}

Another feature of stratified societies was that, when kings or other rulers emerged, the people they employed to implement their governmental decisions were often working outside their family circles. They could thus be said to be employed in the 'public' sector and were the forerunners of the civil service. For instance, as suggested above, writing may have originated in systems used by early bureaucrats to recording transactions, such as the payment of taxes or tributes, in larger agricultural societies - and then developed by those with the time and inclination (Lipsey, Carlaw, \& Bekar, 2005: 145-149).

It has been claimed that the origins of the English civil service lie in the court servants who followed the Saxon kings of England from one place to another (Hennessy, 1990: 18), and such rulers would also have had military servants which again would have been an early form of nonfamily employment. (NB: The term 'civil service' is said to have come from the East India Company which categorized its employees as either military servants or civil servants and the introduction of this terminology from India into England has been attributed to Macaulay's essays on Clive and Warren Hastings which were published in 1840 and 1841; Hennessy, 1990: 17-18.) There could also have been some employment in religious organizations such as monasteries. However, although there had thus started to be some nonfamily employment, a lot of people still worked essentially on a self-employed basis on the land and/or for or in family units.

\section{The next stages}

One nonvoluntary form of work in many agricultural societies was slavery. However, in Western Europe another extractive institution evolved which started to replace slavery or make it largely redundant and that was feudalism. Feudalism is an institution of agricultural societies in which each level of society owed an obligation to the higher level. At the lowest level were the serfs, the majority of the population, who typically farmed for themselves in communal fields, but were also obliged to work for a specified amount of time for their lords. Thus the serfs had little incentive to innovate and work better because any benefit largely went to others and the lords also had little incentive to change because the system already gave them a lot of benefit and, in any case, change was unsettling and therefore threatening.

What seems to have been a trigger for the end of feudalism, at least in parts of Western Europe, was the plague which started to spread there in 1348 and killed many people including about half the population of England. As a result, there was a massive shortage of labour which, because demand for labour exceeded supply, placed the surviving peasants in a relatively strong position where they were encouraged and enabled to demand change. They started to reject compulsory labour service and to ask for, and get, higher wages. Governments may have tried to stop this, and in England the Peasants' Revolt of 1381 was defeated - but nevertheless an inclusive labour market started to emerge (Acemoglu \& Robinson, 2013: 99-100).

Although the plague may have enhanced the bargaining power of the peasants when undertaking work for others, most of them still worked on the land and mainly as families. It would appear that what emerged in England after the end of the feudal system was a rural society which could be classified into three levels. At the top were landlords who mainly rented out their land for others to farm. Then there were a mixed group of self-employed famers including small freeholders with some title to land, others farming rented land and some who had customary usage of common land. Finally, at the bottom were labourers working for wages - but there were no clear sharp divisions between these groups and no clear separation between those who might be considered to be self-employed and those who were not. For instance, a labourer might also farm a small patch of land (as the author has observed some working people still do in places like Romania) and some farming family income might be derived from spinning, weaving or other out-work (Mathias, 1983: 47-48). 
A further development which changed this, however, was the 'enclosure' movement under which the open land of the feudal three field system and other common land was enclosed and reserved for the use of one owner instead of being available for general use. In England this began to be widespread in the 16th century and was particularly prevalent in the 17 th and 18 th centuries. When combined with more productive agricultural practices and a rising population, it created a landless working class for whom self-sufficient agriculture was no longer an option and who had to seek employment working for other people. Even prior to the industrial revolution economic growth in cities drew labour from the countryside (Allen, 2009: 58), but hiring fairs were a feature of life for many agricultural workers who were often taken on only for limited periods of time and on a contract basis.

\section{The emergence of professional workers and nonfamily enterprise}

Not everyone worked on the land and while, feudalism was evolving into contract labour, a variety of specialist professions became established. These professions or occupations would have included manufacturers such as millers, smiths, bakers and leather workers as well as services such as teachers, doctors, artists and musicians. Later other services also developed including lawyers and architects, window cleaners and hairdressers. Many of those occupations would still have been family based, at least in their initial stages, but later evolving into partnerships or self-employment.

But nonfamily enterprise was also starting. An early European form of the production of goods outside the family may have happened in monasteries which produced surpluses of things like beer which they then sold to others. However it was high-risk but potentially high-return geographic exploration, such as the voyages of Columbus, which stimulated the need for a recognized means of creating nonfamily enterprises and in particular for a form of organization which facilitated risk sharing by investors. The outcome was the limited liability company which reduced the personal risk involved in owning a business. Adam Smith is reported to have opposed companies on the grounds that they would lead to owners being less vigilant in monitoring their managers (Chang, 2011: 13). And, until the middle of the 19th century, in England such companies needed a royal charter. Nevertheless it has been said that it was this development which made modern capitalism possible (Chang, 2011: 12). In England, for instance, the East India Company was an early example of a business clearly being established with a separate legal identity as it derived its powers from a Royal Charter of 1600 . However it was in the Netherlands that it might be said that the joint-stock company was invented at this time with the formation of the Vereenigde Nederlandsche Geoctroyeerde Oostindische Compaagnie (United Dutch Chartered East India Company) in 1602 (Ferguson, 2009: 128). Such initiatives went along with and assisted the emergence of a merchant class whose business was in trade more than in farming or artisanal production.

Thus the private sector could be said to have emerged and, with it, the facility for legal investment and recognized forms for starting new businesses which were not self-employed family units. It should also be noted that, when the public and private sectors began to be distinguishable in this way, there were clearly other enterprises which were in neither of those sectors. Thus they are said to have been in the third sector and examples include early schools and hospitals which were neither initiated nor funded by the state and were not formed for the personal financial gain of their founders. It is interesting that some third sector organizations, like Oxbridge colleges, seem to be able to survive far longer than any private sector venture (Bridge \& O’Neill, 2013: 167).

\section{Pre-industrial societies}

Because of such developments by the end of the 17th century many people in the UK no longer worked in family units on the land - and an indication of this is provided by Gregory King who was secretary to the Commissioners for the Public Accounts (Mathias, 1983: 23-25). Because of his 
position he had access to the official statistics of his day for England and Wales and from them he produced an estimate of their population and wealth for 1688 from which Table 2 is an abstract.

These figures present a picture of economic life in parts of the UK shortly before the start of the industrial revolution, but they do indicate that, while at that time traces of family-based subsistence agriculture remained, many people already worked off the land, mostly for someone else, in what would now be considered to be the private sector. Only a small proportion worked for the government, in what would now be called the public sector, and much of that public employment would have been in the armed services.

Another snapshot of a pre-industrial world is provided by McPherson (1990) in his book on the American Civil War in the introduction to which he describes what life was like for many Americans before the transportation revolution refashioned their economy. As late as 1815, he suggests, outside the cities Americans produced for themselves most of the things they needed or bought them from small artisan producers (see Box 1) and it is clear from his description that many of the people in these areas were, in effect, self-employed.

Table 2. The English and Welsh Economy in 1688 (based on Mathias, 1983: 24)

\begin{tabular}{lrr}
\hline \hline Ranks & Families & Individuals \\
\hline Lords, knights, and gentlemen & 16,600 & 153,000 \\
Professional classes (church, navy, army, office holders) & 55,000 & 308,000 \\
Merchants, traders and shopkeepers & 50,000 & 696,000 \\
Artisans and handicraftsmen & 60,000 & 240,000 \\
Freeholders and farmers & 330,000 & $1,730,000$ \\
Labouring and out-servants & 364,000 & $1,275,000$ \\
Cottagers and paupers & 400,000 & $1,300,000$ \\
Others (common soldiers, common seamen, vagrants) & 85,000 & 250,000 \\
\end{tabular}

Note. Table 2 is based on Mathias (1983: 24, table II), reproduced with permission from Taylor \& Francis.

\section{Box 1. The USA in 1815}

'As late as 1815 , Americans produced on their farms or in their homes most of the things they consumed, used, or wore. Most clothing was sewn by mothers and daughters, made from cloth that in many cases they had spun and woven themselves by the light of candles they had dipped or by natural light coming through windows in houses built of local materials from a nearby sawmill or brickyard by local carpenters or masons, or by the male members of the household. Shoes were made by members of the family or by the village cordwainer from leather cured at a local tannery. Blacksmiths forged the tools and farm implements used in the community. Even firearms were built with handicraft skill and pride by a nearby craftsman. In larger towns and cities, master tailors or shoemakers or cabinetmakers or wheelwrights presided over small shops where they worked with a few journeymen and an apprentice or two who turned out fine custom or 'bespoke' goods for wealthier purchasers. In an age of slow and expensive overland transport, few of these items were sold more than twenty miles from where they were made' (McPherson, 1990: 13). 


\section{The industrial revolution}

Many economies had not been static prior to the 18th and 19th centuries but, nevertheless, the change produced by the industrial revolution was on a different scale. It is hard to set a date for the start of the industrial revolution, but it seems reasonable to think that it began in England in the 18th century and Morris has suggested that the year 1776 can be seen as a sort of symbolic turning point. That was not only the year of the American Revolution and the year in which Adam Smith finished his Wealth of Nations and Edward Gibbon's Decline and Fall of the Roman Empire was published, but it was also the year in which Watt and Boulton demonstrated that their improved steam engine could pump 60 feet of water out of a mine in 60 minutes (Morris, 2011: 490-497).

The application of steam power was a crucial factor. The mechanization of textile manufacture had been a long-term European project possibly initiated by Leonardo da Vinci (Lipsey, Carlaw \& Bekar, 2005: 243), but the move of textile manufacture from homes into factories was necessary for the harnessing of water and then steam to power that mechanization. The development of textile machines might own more to the tinkering of intelligent craftsmen than the application of science, but harnessing steam power depended on the application of the relevant science. It also needed investment and inclusive institutions (see Box 2) were needed to encourage people to invest the time and resources needed. As England had both science supported by free universities and potential investors encouraged by an inclusive regime, as well as other relevant factors, it was in England that the industrial revolution started and grew - and work in England started to change as a result (e.g., Lipsey, Carlaw, \& Bekar, 2005).

Some people were not helped by this change. The aristocracy may have suffered because their income mainly came from the land they held - either from renting it out to tenant farmers or from farming it directly - and the revolution took people from the land and thus reduced land rates and raised wage rates. Also artisans with manual skills lost work as machinery took over many of their tasks. However in England neither the aristocracy, which in other countries controlled the government, nor the artisans, who elsewhere had formed powerful and restrictive guilds, had the power to prevent such change - and the economy overall benefitted (Acemoglu \& Robinson, 2013: 85). The inability of powerful groups to put themselves above the law, or to change it to favour their interests, is an aspect of what Acemoglu and Robinson have called an inclusive regime (see Box 2 ) and was an essential factor in enabling this economic development.

The effects of the industrial revolution were wide reaching. They included developments in energy capture, which Morris suggests is the single biggest factor in the sudden and extensive rise in the economic development of the West as reflected in his 'social development index' (Morris, 2011). It also included the transport revolution which, by reducing the cost of moving raw materials and of shipping finished goods, led to more specialization and to the concentration of effort known as Fordism (see below). Economies of scale in production and the low cost of distribution enabled an extensive range of goods to be made available widely and cheaply available - which in turn meant an end to self-sufficiency as a realistic option of many people. The industrial revolution thus changed many people, from generating resources by working for themselves or others on the land, to living in cities and working there for others, often in large factories. As late as the beginning of the 20th century $50 \%$ of the population of the USA still worked on the land, whereas at the start of the 21st century it was only $2 \%$ - although that $2 \%$ was much more productive (Baumol, Litan, \& Schramm, 2007: 17).

\section{Fordism}

The industrial revolution both enabled and encouraged the rise of manufacturing and of big businesses. Bigger businesses had the critical mass necessary to justify investment in the power plant and specialist 


\section{Box 2. Inclusive regimes}

There can be great danger in trying artificially to preserve a way of working because some, but not all, elements of society want it. Acemoglu and Robinson suggest that 'countries differ in their economic success because of their different institutions, the rules influencing how the economy works, and the incentives that motivate people' (2013: 73). In particular, they distinguish between the institutions they label 'inclusive' and those they label 'extractive'. Inclusive institutions have at their centre secure property rights and they foster economic activity - whereas extractive institutions are designed to extract income and wealth from one subset of society for the benefit of another, often a ruling elite.In inclusive regimes no one, not even the ruler, is above the law or can unilaterally change the law to suit their own purposes - and, according to Acemoglu and Robinson, an inclusive regime was an essential prerequisite for the industrial revolution. In other counties in Europe, there were many examples of aristocracies and elites who had very good life-styles themselves and had a vested interest in maintaining the status quo and were thus potential losers from industrialization. For instance guilds of artisans stood to lose from the introduction of new manufacturing techniques and therefore wanted to maintain the restrictive laws in other European countries - and sometimes had sufficient political influence to do this. And even as late as the beginning of the 20th century the Tsars in Russia were resisting factories and railways, and therefore wanted laws which restricted them, because they thought they would encourage and facilitate workers to congregate in large groups where they might foment revolution.

According to Acemoglu and Robinson England, along with the USA and Australia, were rare examples of inclusive regimes - and in England's case this was due in a major part to the inheritance of Magna Carta in 1215, the English Civil War between 1642 and 1651 and the Glorious Revolution of 1688. Therefore, England was a place where the industrial revolution could flourish - and other countries were not. Even in Britain there was a reaction against industrialization by people like aristocrats and artisans, because by taking people of the land it reduced rental rates for land owners and the availability of cheap labour to work their land, and by mechanization it reduced the demand for the manual skills of artisans. But aristocratic land owners were not more powerful than an inclusive law and those artisans, such as the Luddites, who attempted to destroy the new machines similarly did not have enough support.

Extractive regimes may have seemed like the norm - but it was a norm against which the inclusive approach had to be jealously guarded. In countries such as Austro-Hungary and Russia, where absolutist monarchs could and did block progress, economic progress stalled even when other European nations followed the industrial lead of England.

machinery which greatly increased the potential output per employee (labour productivity) and meant that goods could be produced at relatively low unit costs. However that generally required the machines to be located in factories to which the labourers would come to work at set times, instead of 'putting out' work which they did on a contract basis at home. These large plants could capture market share because they could produce a lot and sell it cheaply - but they also needed that market share because they needed to sell a lot to recoup the cost of the machinery, and the cost of the plant needed to supply power for it. This is the effect of economies of scale and led to a trend towards larger plants with lower unit costs accompanied also by horizontal and vertical integration. The latter were needed to put on the same site as many parts of the overall process as possible in order to be able to control and coordinate them. 
A significant exponent of this, after whom the process has been named, was Henry Ford with his car production lines. These enabled him to produce cars very cheaply provided they were an unvarying standard product: 'any colour you like as long as it is black' (Ford, 1922: 72, paraphrase). Ford, it is reported, actually paid his production line employees well to retain their services for such boring repetitive work but Fordism nevertheless put large manufacturers in a very strong labour bargaining position. Therefore a counter-balance was needed or, as Galbraith (1957) put it, a countervailing power which came from strong unions and government regulation: resulting in a triumvirate sometimes referred to as 'big business, big labour and big government'. Work at the time has been characterized as 'male-dominated involving blue-collar manufacturing jobs in a fixed worksite with lifetime jobs often protected by a tariff as well as collective agreement or employment standards legislation established and monitored by governments that had the power and discretion to enforce regulatory initiatives' (Gunderson, 2013: 23). Nevertheless it is this era of work which forms the folk memory of many people still alive today and, it seems, has become the archetype in many people's minds for work should be.

\section{An apparent decline of small businesses}

In the middle of the 20th century, Fordism, with its large integrated production plants and its economies of scale, seemed to be the future. While there were still many small businesses, often they were not recognized as being in any significant way distinct from bigger businesses. The author still has the first business text book he was advised to read which was initially published in 1958 (Edwards \& Townsend, 1967) and, from today's perspective, it can be more interesting for what it does not say than for what it does include. For instance, while it does indicate that many businesses are, or at least start, small, nowhere does it consider small businesses as a distinct category different from big businesses and therefore worthy of separate consideration.

Where small businesses did receive some recognition at this time it was because their apparent decline had led to them being seen almost as an endangered species. For example in the USA the Small Business Administration was established in 1953 to help to preserve the small business sector there and in the UK the Committee of Inquiry on Small Firms (the Bolton Committee) was set up in 1969 under the chairmanship of J E Bolton to consider the role of small firms in a modern economy (Bolton, 1971). Therefore, it would be fair to say, in both administrations at that time, where small businesses were recognized as a relevant category worthy of official concern, any resultant policy was largely preservationist, not expansionist (Bridge \& O’Neill, 2013: 16-18). Instead, because of developments such as Fordism and the industrial effort stimulated by the Second World War, and the stable levels of relatively full employment that followed that conflict, it seemed that most people in the more developed countries could, if they acquired an appropriate skill, expect to have a job for life mainly as an employee of some form of large enterprise.

\section{The third wave}

However, the ascendancy of big business has not lasted. After almost three decades of seeming stability after the Second World War something changed and unemployment started to rise in many countries in the 1970s. In 1980, in his book The Third Wave, Toffler suggested that significant waves of change in human development had followed the agricultural and industrial revolutions. The first wave, triggered by agriculture, had by then reached all but a very few remaining tribal societies and the second, with its accompanying industrialization, had reached many people but was still not entirely spent. Nevertheless, he suggested, they were already being succeeded by a third wave. What Toffler thought that third wave was seems to be less clear. However he mentioned Silicon Valley and solid 
state physics as well as electronics and computers, plus the space industry and exploring the seas' depths, and biology and genetics - and it now seems that it was the first four of those which have had the greatest impact.

Others also saw a difference and, as Brown and Julius (1995) have described, in developed countries there has been a shift from manufacturing to services. Just as the industrial revolution (Toffler's second wave) had led in developed countries to a move of employment away from the land, so too the third wave was being accompanied in the same countries by a move of employment away from manufacturing. And it is also relevant that services can be less dependent on economies of scale and therefore more likely to be delivered by small businesses or the self-employed.

However, the move away from the land did not mean less food production. Often more food was produced but by mechanized working which was much more efficient and needed less labour. Nevertheless countries with limited space and with rapidly rising populations, like England, also needed to import more food and therefore, in effect, to export some food production. Also the labour that moved from the land did not all move into manufacturing industry but, as Brown and Julius report, predominately into the service sector. Today manufacturing is not the distinctive prerogative of a developed country and, they observe, manufacturers who want to compete on cost are shifting manufacturing to developing countries and those who want to compete on high value added will have to raise their intensive customization and associated services - and both these routes will hasten an employment shift to services. Therefore, Brown and Julius suggest, manufacturing should now no longer be seen as special and that, overall, momentum has been 'building for a global economic transformation'. (Brown \& Julius, 1995: 275).

According to Audretsch et al. this has led to a major shift in the organization of developed economies away from managed economies, where economic performance 'is positively related to firm size, scale economies and routinized production', towards entrepreneurial economies where performance is related to distributed innovation and the emergence and growth of innovative ventures' (Audretsch, Thurik, \& Stam, 2011: 3). The fundamental catalyst for this, they find, has been technological change and in particular the emergence of information and communication technologies but, they add, there have been other factors involved also including globalization, the demise of the communist system and rising levels of prosperity.

Information and communication technologies, they suggest, has significantly reduced the marginal cost of communication, so small firms can compete on even terms, and this has been accompanied by an increased reliance, not on organization, but on knowledge and innovation where small enterprise can have a distinct advantage. Customers want variety, if they can have it cheaply, and because information and communication technologies facilitates control, and even the supply of some services, at a distance, single site integration is no longer necessary for control. Therefore single site conditions and overheads do not have to apply and subcontracting to small, more flexible organizations can be cheaper and/or the source of more variety and more innovation. This provides more scope for people to work how they like to work, but also for more and faster change. So enterprise, innovation and flexibility are keys to success - and they are all compatible with self-employment.

Therefore, while the third wave may still be relatively new, and its full nature and lasting impact therefore hard to assess, it does seem that, in terms of people's work options, it will lead to more change, fewer jobs for life, more opportunities for innovation and small enterprises - and for self-employment, and more dependence on thinking and knowledge rather than on dexterity and manual skills.

\section{EMPLOYMENT - OR SELF-EMPLOYMENT}

That is a very brief summary of a very long history but it does present the world of work as one of evolution through periodic change. Within this there have been times of apparent stability, such as the era the feudal system, in which the status quo seems to have been accepted as the long-term norm - and recently there has 
been a period in which plentiful, big business-based, lifetime employment seemed to be, if not actually the norm, at least realistically the preferred work system for many people, supported by their governments. But this period has been relatively short. Although it was a historically recent development, there are reasons to think that its peak may already be over and the more advanced economies are already moving on. However a perception of the superiority of employment over self-employment may be a legacy of this - and therefore the following comments on this history may also be relevant.

It was as a result of the industrial revolution and Fordism that 'jobs' and 'employment' as we now know them really emerged. The period from 1840 to 1990 has been described as the 'age of the job' because it was only after 1840 that people started to have fixed hours of work and to be paid salaries (Bridges, 1998: 50). However, according to Urwin (2011), it was only at the start of 20th century that a clear distinction between 'employees' and the 'self-employed' really emerged. Before that, he indicates, while employers may have held the balance of power in the years before widespread unionization, workers were not systematically held to fixed periods of notice and the relationship between business owners and workers was more or less the same as that which had prevailed for itinerant workers since antiquity. However, it has been suggested that it was the use of specialized factory machinery which led employers to want to exert greater control over large numbers of workers, for instance to facilitate shift working and maximize the use of expensive plant. The employers therefore wanted enforceable contracts of employment and the workers organized to demand things like holiday and sick pay in return. Thus, largely through case law, the distinction emerged between those who were employed long-term under a contract of service and those who were instead self-employed and worked on short-term contracts for services.

Therefore whether workers became employees or self-employed depended to a considerable extent on the trade they had chosen, or been encouraged, to follow. Those working in industry and whose skills were required every day largely became employees but others, whose skills were only needed occasionally and for relatively short periods, remained self-employed. So those people who trained as welders or machinists are likely to be employed whereas hairdressers and window cleaner have acquired trades in which many people were and are self-employed - as did lawyers and similar 'professionals'.

Therefore the category of self-employment now covers many possibilities - for example from architects and artists through mercenaries and contract managers to water-diviners and window cleaners. As Bögenhold, Heinonen, \& Akola, observe: 'differences between positions within self-employment can be higher than differences between individual self-employed people and employees' (2013: 9). Self-employment includes many people who work as freelancers (see Box 3) in fields such as journalism and translation, often because they do not want to be tied to a permanent full-time job - and it also includes many artists. Some of those who work on a freelance basis might consider themselves to be professionals, a category which also includes people such as architects, doctors and lawyers. Bögenhold et al. also refer to a long-lasting debate on the question of whether professionals act differently to 'regular' businessmen. Classically, they suggest businessmen have been supposed to have an 'egoistic' motivation, 'pursuing [their] self-interest regardless of the interests of others', whereas liberal professionals 'altruistically serve the interests of others regardless of their own' (Bögenhold, Heinonen, \& Akola, 2013: 7). Although some professionals might join partnerships rather than work on their own, nevertheless, as Bögenhold et al. suggest, they can be regarded as self-employed, albeit in a subset of the self-employment spectrum.

\section{And the future?}

Clearly there are expectations that these trends will continue. Shackleton, in commenting on an enquiry into self-employment being undertaken for the UK Deportment for Business, Innovation and Skills, reports that in the UK self-employment jobs have grown faster than employee jobs since the 


\section{Box 3. The origin of the term 'freelance'}

One area of employment in which a form of contract service had emerged at an early date earlier was warfare. While many soldiers would have been recruited by their rulers either voluntarily or compulsorily to fight for their side, other soldiers were mercenaries who fought for whoever would pay them. One type of mercenary who found ready employment in 16th and 17 th century were lancers or pikemen. A lance is a spear-like weapon which was used by cavalry and then, in a longer form also known as a pike, used by infantry as a weapon against cavalry. So successful was this application that lances and/or pikes were used in almost every European army and the men who knew how to wield them could, if they wished, become highly sought-after mercenaries. Those mercenaries were not tied just to one cause but were free to use their lances for whoever was prepared to pay for them. Thus, in 1819 in his novel Ivanhoe, Sir Walter Scott used the term 'freelance' to describe a mercenary warrior of the medieval period - a soldier who fought not exclusively for just one cause but who could be hired by any side for an agree period:

'I offered Richard the service of my Free Lances, and he refused them. (But) ... thanks to the bustling times, a man of action will always find employment' (Scott, 1982: 317).

recession. However a contributory factor is a fall in the number leaving self-employment, which suggests that those who are self-employed are relatively content with that situation - and they report themselves to be happier (Shackleton, 2016).

Self-employment is also a significant feature in other countries. According to the International Labour Organization there has been 'a shift away from the standard employment model in which workers earn wages and salaries in a dependent employment relationship vis-à-vis their employers, have stable jobs and work full time' - with the result that 'today, wage and salaried employment accounts for only about half of global employment' (International Labour Organization, 2015: 13). According to the OECD self-employment rates in 2015 varied from about $6 \%$ of employment in Luxembourg to about $55 \%$ in Columbia with $14.5 \%$ in the UK, $17 \%$ for the EU overall and $25.1 \%$ in Italy. (OECD, 2015). And the self-employed are not necessarily accepting a lower income than their employed counterparts. The International Labour Organization, in reporting on the world outlook, also notes that in Italy the average annual income from self-employment is $>100 \%$ of the annual average wage income, and that for the UK it is over 90\% (International Labour Organization, 2015: 40).

\section{IN CONCLUSION}

While work may have been a constant feature in human existence, the nature of the work open to many people has changed. Tofler's three waves have each had an impact and the changes from huntergathering to agriculture and then to manufacturing and now to post-manufacturing indicate that economies evolve and continue so to do.

However perceptions often lag behind the reality and, while the most advanced economies may again have more niches for smaller units and be more service focussed, often attitudes, both private and public, still seem to be based in the previous era. Many people working today were born in a time when big business, with its associated features such as jobs for life, seemed to have been the norm, so that was the environment that they came to understand, and to expect and want. As Galbraith's ideas on countervailing power (see above) indicate, the approach of many governments to regulating and taxing businesses was a response established towards the height of Fordism when it seemed that big 
businesses were predominant and were likely to remain so. Similarly, organized labour in the form of unions was largely established in response to big business pressures and was structured for that context.

But have government and/or union attitudes changed? As Gunderson observes, 'the labor policies of Western developed countries were generally established in an earlier era when the nature of work was quite different from what it is today'. Although Fordism was only predominant for what was, historically speaking, a relatively short period, it and the institutions associated with it have come to be seen as the archetypical work regime. But, as Gunderson also points out, 'the new world of work is vastly different [and] in such circumstances, it would be surprising if the labor regulations previously established for the old world of work were appropriate and relevant to the new' (Gunderson, 2013: 23). Nevertheless it can be argued that, to a considerable extent, the previous big government and big labour approaches continue - and that they combine when labour parties enter government. If so the following reflections by Paul Keating, the former Labour Prime Minister of Australia, provide a relevant comment:

The party (Labour) is not open to the new professional and business classes.... That [self-employed] person should be a Labour person but we've let them go. We've lost them. As the nature of the workforce has changed we haven't changed with it (O'Brien, 2015: 761).

Such perceptions may have formed at the time of the ascendancy and seeming hegemony of big business, but the above analysis suggests that they were not universally relevant then and even less correct now. For instance

- There have always been small enterprises, including one-person self-employment businesses, and, even when their basis moved beyond just the family, many enterprises were still small (and often provided local services).

- The era of big business and 'the job' was, in historical terms, a relatively short-lived development and conditions such as hunter-gathering and feudalism had each been the norm for much longer.

- While for some people long-term 'contract of service' jobs may seem to be desirable, that form of employment is neither the original nor the ultimate form of work. It is not the form from which others are deviations and shorter term, 'contracts for services' have a much more extensive history and have been the norm for many people for much longer.

- Services have always been the basis of much non-agricultural employment and, with the changes in manufacturing, may again be on the increase in some countries. And services are necessary, not just for people, but also to support businesses and other organizations. They too are a fundamental part of a modern economy.

- Full-time employment in one job was never universal and, throughout much of employment history, many people have had portfolio and/or part-time jobs, whether from necessity - for instance a farmer who wants to work on the land but needs to support that with some off-farm work - or desire - for instance someone who combines being an artist for self-expression with being an arts teacher for social contact and some steady income.

In most parts of the world, hunter-gathering and feudalism did not last forever and, it appears, neither has Fordism - but do our attitudes and beliefs reflect this reality, or do we need to change outdated thinking? Old beliefs which might be questioned include

- An assumption that big business is the norm and big business thinking should prevail.

- An assumption that businesses exist to make profits for their owners - and that is all the people behind them want? What are the consequences of such thinking and where does it fit with Maslow's hierarchy? We may recognize self-actualizing in the work of artists but what about that of other self-governing professionals. 
- An assumption that the normal form of work, and the preferable/desirable form, is (and always has been) full-time employment in a large business.

- An assumption that small businesses, including self-employment, are a subset of business - and that, in business, big business approaches are archetypical.

Often we become accustomed to thinking and acting on the basis of received wisdom but should we now recognize that often much of our received wisdom about employment is out of date? Instead should we recognize that the world of work continues to change and, while new thinking may not all be correct, not recognizing that change, and not responding accordingly, will only serve to hinder progress, not to prevent it?

\section{ACKNOWLEDGEMENT}

This manuscript is an original work and has not been submitted nor published anywhere else.

\section{References}

Acemoglu, D., \& Robinson, J. A. (2013). Why nations fail: The origins of power, prosperity and poverty. London: Profile Books.

Allen, R. C. (2009). The British Industrial Revolution in global perspective. Cambridge: Cambridge University Press.

Audretsch, D. B., Thurik, A.R., \& Stam, E. (2011). Unraveling the shift to the entrepreneurial economy. Zoetermeer: EIM.

Baumol, W. J., Litan, R. E., \& Schramm, C. J. (2007). Good capitalism, bad capitalism, and the economics of growth and prosperity. New Haven, CT and London: Yale University Press.

Bögenhold, D., Heinonen, J., \& Akola, E. (2013). Entrepreneurship and Independent Professionals: Why do professionals not meet with stereotypes of entrepreneurship, IFS Discussion Paper No. 04/2013, Austria, Klagenfurt, Department of Sociology, Alpen-Adria-Universität.

Bolton, J. E. (Chairman) (1971). Report of the committee of inquiry on small firms. London: HMSO.

Bridge, S. (2010). Rethinking enterprise policy. Basingstoke: Palgrave Macmillan.

Bridge, S., \& O’Neill, K. (2013). Understanding enterprise, entrepreneurship and small business. Basingstoke: Palgrave Macmillan.

Bridges, W. (1998). Redefining work. RSA Journal, 1(4), 50-53.

Brown, R., \& Julius, D. (1995). Is manufacturing still special in the new world order?. in J. Drew (Ed.), Readings in international enterprise (pp. 275-285). London: Routledge.

Chang, J-H. (2011). 23 things they don't tell you about capitalism. London: Penguin.

D'Arcy, C., \& Gardiner, K. (2014). Just the job - or a working compromise? The changing nature of self-employment in the UK. London: Resolution Foundation.

Diamond, J. (1998). Guns, germs and steel. London: Vintage.

Edwards, R. S., \& Townsend, H. (1967). Business enterprise: its growth and organisation. London: Macmillan.

Ferguson, N. (2009). The ascent of money. London: Penguin Books.

Ford, H. C. S. (1922). My life and work. New York: Garden City Publishing Company, Inc.

Galbraith, J. K. (1957). American capitalism, the concept of countervailing power (revised edition), London: Hamish Hamilton.

Gunderson, M. (2013). Chapter 2 - changes in the labour market and the nature of employment in western countries. in K. V. W. Stone, \& H. Arthurs (Eds), Rethinking workplace regulation (pp. 23-41). New York: Russell Sage Foundation.

Hatfield, I. (2015). Self-employment in Europe. London: Institute for Public Policy Research.

Henley, A. (2015). 'The post crisis growth in the self-employed: Are they a volunteer army?, Paper presented at the 38th ISBE Conference, November, Glasgow.

Hennessy, P. (1990). Whitehall. London: Fontana Press.

HM Revenue \& Customs (2009). False self-employment in construction: taxation of workers. London: HM Treasury. Retrieved January 9, 2009 from www.hm-treasury.gov.uk.

International Labour Organization (2015). World employment and social outlook: The changing nature of jobs. Geneva: ILO. 


\section{Simon Bridge}

Kochlar, R., Kim, P., \& Rohal, M. (2015). Three-in-ten US jobs are held by the self-employed and the workers they hire. Washington, DC: Pew research Centre.

Lipsey, R. G., Carlaw, K. I., \& Bekar, C. T (2005). Economic transformations: General purpose technologies and long term economic growth (pp. 144-150). Oxford: Oxford University Press.

Maslow, A. H. (1943). A theory of human motivation. Psychological Review, 50(4), 370-396.

Mathias, P. (1983). The first industrial nation: An economic history of Britain 1700-1914. London: Methuen.

McPherson, J. (1990). Battle cry of freedom. London: Penguin.

Morris, I. (2011). Why the west rules - for now. London: Profile Books.

O’Brien, K. (2015). Keating. Crows Nest, NSW: Allen \& Unwin.

OECD (2015). Employment Outlook, Retrieved March 26, 2016 from https://data.oecd.org/emp/self-employmentrate.htm.

Scott, Sir Walter (1819/1982). Ivanhoe. London: Guild Publishing.

Shackleton, L. (2016). Self-employment: entrepreneurship or casualised labour? Retrieved March 26, 2016 from www. iea.org.uk/blog/self-employment-entrepreneurship-or-casualised-labour.

Toffler, A. (1980). The third wave. London: Collins.

Urwin, P. (2011). Self-employment, small firms and enterprise. London: Institute of Economic Affairs in Association with Profile Books. 